http://kitaibelia.unideb.hu/

ISSN 2064-4507 (Online) • ISSN 1219-9672 (Print)

(C) 2015, Department of Botany, University of Debrecen, Hungary

21 (1): 27-32.; 2016

DOI: $10.17542 /$ kit.21.27

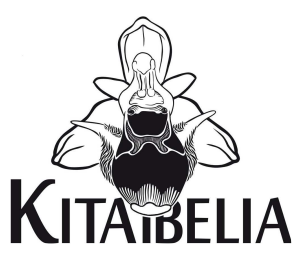

\title{
Új orchideafaj a magyar flórában: Epipactis pseudopurpurata Mered'a
}

\author{
CSÁBI Miklós ${ }^{1}$ \& HALÁSZ Antal² \\ (1) H-1035 Budapest Kerék u. 4.; csmfoto@freemail.hu \\ (2) Duna-Ipoly Nemzeti Park Igazgatóság; halasz.antal@dinpig.hu
}

\section{Epipactis pseudopurpurata Mered'a, a new orchid species for the Hungarian flora}

\begin{abstract}
A small population of Epipactis pseudopurpurata new to the flora of Hungary was found in the Buda Mts, near Telki village (Pest county). The main diagnostic features of this species are discussed, and a comparison with the allied species, E. purpurata is provided.
\end{abstract}

Keywords: autogamy, Buda Mts, Epipactis, flora, Hungary, gynostemium, orchid

Összefoglalás - A Budai-hegységben, Telki határában a magyar flórára új fajként megtaláltuk az Epipactis pseudopurpurata kis állományát. Ismertetjük a faj főbb jellemzőit és összehasonlítjuk a rokon E. purpurata-val.

Kulcsszavak: Budai-hegység, Epipactis, ivaroszlop, flóra, Magyarország, orchidea, önmegporzás

\section{Bevezetés}

Az elmúlt évtizedekben számos új Epipactis-fajt írtak le Közép-Európából, később többségük magyarországi jelenléte is ismertté vált (MoLNÁR 2003). Az utóbbi évtizedekben került elő hazánkból többek között az E. bugacensis Robatsch (RoBATSCH 1990), E. pontica Taubenheim (SUlYOK \& MolnÁr 1996), E. mecsekensis Molnár \& Robatsch (MolnÁR \& RoBATSCH 1997a), E. tallosii Molnár \& Robatsch (MolnÁr \& ROBATSCH 1997b), E. voethii Robatsch (MolnÁr et al. 2004), E. futakii Mered'a \& Potucek (Somlyay 2010), E. latina (W.Rossi \& E.Klein) B. \& H. Baumann (SUlYOK 2011) és az E. peitzii H.Neumann \& Wucherpfennig (SomLYAY et al. 2016).

Az E. pseudopurpurata-t 1996-ban P. Mered'a írta le Szlovákiából, a Sztrázsó-hegységből, eddig csak Szlovákiában (MERED’A 1996) és Csehország délkeleti részéből (BATOUŠEK 2009) volt ismert.

\section{A hazai előfordulás}

2013. július elején a Telki közigazgatási területéhez tartozó Vasvári-erdőben található Epipactis purpurata Sm. állomány vizsgálata során került elő egy kistermetű, kis levelű Epipactis taxon néhány bimbós példánya. Már akkor az E. pseudopurpurata előkerülésére gyanakodtunk, de ezt csak július közepén tudtuk biztosan megállapítani, amikor a területre visszatérve a korábban látott töveket virágzó állapotban is meg tudtuk figyelni. Az ekkor készített fényképek alapján a határozást Molnár V. Attila és Pavol Mered'a egyaránt megerősítették. A 2013-as megtaláláskor a faj három virágzó és néhány, a szárazság 
következtében elszáradt, illetve sérült példányát észleltük. 2014-ben növényünk nem virágzott, csupán egyetlen, bimbós állapotban besült tőre bukkantunk. 2015-ben viszont - a korábban látott tövek tágabb környezetében is - összesen 16 virágzó hajtást számoltunk (1. ábra). Az állomány völgytalpi gyertyános-tölgyesben, 430 méter tengerszint feletti magasságban, erősen vadjárta, nudum területen helyezkedik el, néhány más orchideafaj (Cephalanthera longifolia (L.) Fritsch, C. rubra (L.) Rich., E. helleborine (L.) Crantz., E. purpurata Sm., Neottia nidus-avis (L.) Rich.) társaságában.

A fajnak mostanáig biztos magyarországi adata nem volt, bár DeviLLeRs \& DevilLeRsTERSCHUREN (2000) beszámoltak Magyarországon talált példányokról: „E. pseudopurpurata, described from the Slovakian Carpathians, was found on 7 August 1991 in a beech forest within the Kiserleti Nature Reserve of the Bakony range, in western Hungary, apparently a first record for the country". A faj illusztrációjaként DELFORGE (2001: 69.) J. Devillers-Terschuren 1991.08.07-én, a Bakonyban készült fényképeit közölte. A részletfotón egyértelműen $E$. purpurata virágzata látható (a virágokban megfigyelhetők a viscidiumok, jól látható a nagy bibefelület, ami hegyesszöget zár be az ivaroszlop tengelyével). Delforge könyvének újabb kiadásban (DELFORGE 2006: 84.) a korábbi részletfotó helyett már egy, Trencsénteplic mellett készült, valóban E. pseudopurpurata-t ábrázoló kép szerepel, a mellette szereplő bakonyi habitusképen viszont nem láthatók a faji bélyegek. Tőlünk és egymástól függetlenül Pavol Mered'a és Molnár V. Attila is arra az álláspontra jutott, hogy DevilLeRs \& DEvilLeRsTERSCHUREN (2000) a Bakonyban 1991-ben Farkasgyepű mellett talált növénye valójában $E$. purpurata, ezért az E. pseudopurpurata általuk közölt bakonyi adata tévesnek tekintendő. A faj így sem az Új magyar füvészkönyvbe (MolNár 2009), sem Magyarország orchideáinak atlaszába (MolNÁR 2011) nem került be. A budai-hegységi populáció tükrében azonban újabb állományok előkerülése várható Magyarország más hegyvidékein is.

A faj magyar elnevezéseként - eredeti leírása helyére utalva - a trencséni nőszőfü nevet javasoljuk.

\section{Alaktani és fenológiai jellemzők}

Nagyon apró termetű, 15-25 cm magas, magányos hajtásokat fejlesztő faj. Szára igen vékony, zöldesbarna (esetleg ibolyás), alul szinte csupasz, a virágzatnál sűrűn szőrös. A lomblevelek száma 1-3, a legnagyobb levél hossza 25-40 mm, szélessége 12-19 mm. A kevés, kisméretü levél tojásdad-lándzsás, sötétzöld, a csúcsa felé halvány lilás futtatással, a fonákán kissé erősebb lilás színnel, ami a virágzás előrehaladtával fokozatosan halványul, szürkészölddé válik. A virágzat laza, viszonylag kevés (3-)7-12(-17) virágú, többé-kevésbé egyoldalú. A murvalevelek lándzsásak, az alsók kissé hosszabbak, mint a virágok. Virágai kicsik, enyhén bókolnak, ritkán nyílnak szélesre, néha kleisztogámok. A külső leplek tojásdad-lándzsásak, kívül zöldek, belül sárgászöldek, a belsők valamivel kisebbek, világosabbak, fehér alapon sárgás, zöldes árnyalattal. A hypochil sekély, kevés nektárt termel, kívül fehér, belül halvány, sárgás, zöldesbarna, fehér szegéllyel. A mesochil és az epichil széles, utóbbi szív alakú, fehér, közepe halvány sárgászöld árnyalatú, az epichildudorok alig emelkednek ki. Az ivaroszlop rövid, a portok hosszan túlnyúlik a bibefelületen, a pollinium szinte a bibefelületen ül, a viscidium és a rostellum hiányzik, a bibefelület merőleges az ivaroszlop tengelyére (2. ábra A, C). A virágok önmegporzással termékenyülnek meg. A magház sötétzöld, alig szőrös, a kocsány sötét, barnáslila.

A hajtások a Budai-hegységben júniusban jelennek meg a talajfelszín felett, az első virágok az eddigi megfigyelések alapján július 15-20-a között nyílnak ki, az utolsó virágok mindkét évben július 26-án már elnyílóban voltak. Az egyes virágok tehát rendkívül rövid ideig nyílnak, a nyári hőségben 10 nap alatt az egész állomány elvirágzik. A virágzás július közepe és augusztus eleje közé eshet. 


\section{Az Epipactis purpurata és E. pseudopurpurata elkülönítése}

Az E. pseudopurpurata leginkább az E. purpurata kistermetű, gyenge példányaival téveszthető össze, de többnyire még azoknál is kisebb, vékonyabb szárú, kevesebb és kisebb virágú. Az E. purpurata hajtásai jellemzően csoportosan jelennek meg, míg az E. pseudopurpurata magányos hajtásokat fejleszt.

A magyarországi példányok lilás színezettsége kifejezetten halvány, néha alig látható. Az E. purpurata többnyire sokkal intenzívebben lilás, a levelek, a szár, de az epichildudorok is hangsúlyosan rózsás/lilás árnyalatúak.

A fő megkülönböztető bélyeg a viscidium megléte (E. purpurata) ill. hiánya (E. pseudopurpurata), de a trencséni nőszőfű ivaroszlopának struktúrája egészen más, az obligát autogám fajok ivaroszlopához hasonló (E. muelleri típusú).

A határozást nehezítheti az esetleges - eddig nálunk nem ismert - hibridek jelenléte. Csehországban ismertek az E. purpurata és E. pseudopurpurata közti átmeneti alakok (többékevésbé fejlett rostellummal és funkcióképtelen viscidiummal) amelyet hibridként, $E$. ×merediorum Batoušek néven írtak le (BATOUŠEK 2009). A hazai állományban talált példányok meglehetősen egységes képet mutattak, mindegyik példány első pillantásra megkülönböztethető volt a közeli $E$. purpurata tövektől. 2015-ben a két faj egyazon lelőhelyen előforduló 10-10 példányán alaktani méréseket végeztünk, amely lehetővé teszi a két taxon összehasonlítását (1. táblázat).

1. táblázat. Az Epipactis pseudopurpurata és E. purpurata főbb morfológiai jellemzőinek összehasonlítása (Vasvári-erdő, Telki, Budai-hg.), 10-10 példány alapján

Table 1. Comparison of the main morphological characters of Epipactis pseudopurpurata and E. purpurata (Vasvári-erdő, Telki, Buda Mts, $\mathrm{n}=10-10$ )

\begin{tabular}{|c|c|c|}
\hline & E. pseudopurpurata & E. purpurata \\
\hline Növény magassága/Height of plant $(\mathrm{cm})$ & $(14,7-) 18,6(-25,3)$ & $(28,4-) 39,1(-55,7)$ \\
\hline Virágzat hossza/Length of inflorescence (mm) & $(27-) 53,5(-101)$ & $(81-) 144,3(-228)$ \\
\hline $\begin{array}{l}\text { Virágzat hossza/magasság/Inflorescence } \\
\text { length/plant height ratio }\end{array}$ & $(0,17-) 0,28(-0,4)$ & $(0,28-) 0,36(-0,43)$ \\
\hline Virágok száma/Number of flowers & $(3-) 9,6(-17)$ & $(13-) 31,7(-44)$ \\
\hline $\begin{array}{l}\text { Szár átmérője a virágzat alatt/Width of stem near } \\
\text { the inflorescence (mm) }\end{array}$ & $\sim 1,5 \mathrm{~mm}$ & $(2,6-) 3,53(-4,2)$ \\
\hline Lomblevelek száma/Number of cauline leaves & $(1-) 2,4(-3)$ & $(4-) 6,4(-10)$ \\
\hline $\begin{array}{l}\text { Leghosszabb lomblevél hossza/Length of the } \\
\text { longest cauline leaf (mm) }\end{array}$ & $(27-) 34,6(-40)$ & $(40-) 49,1(-56)$ \\
\hline $\begin{array}{l}\text { Leghosszabb lomblevél szélessége/Width of the } \\
\text { longest cauline leaf ( } \mathrm{mm})\end{array}$ & $(12-) 14,1(-19)$ & $(11-) 15,8(-24)$ \\
\hline
\end{tabular}

Szintén sor került az ivaroszlopok összehasonlítására. A két faj, bár feltételezhetően közeli rokona egymásnak, mégis teljesen más felépítésű ivaroszloppal rendelkezik. Az $E$. purpurata virágaiban - tipikus idegenmegporzású fajként - fejlett rostellum és nagy, kiemelkedő, funkcióképes viscidium található (2. ábra B, D), ami erősen kapcsolódik a polliniumhoz, amely így nagyon könnyen, egyben eltávolítható a portokból. Az ivaroszlop két oldalán fejlett sztaminódiumok figyelhetők meg. Az E. pseudopurpurata ivaroszlopából mindezek hiányoznak (2. ábra A, C), a szaporítószervek teljes mértékben a hatékony önmegporzáshoz formálódtak. A virág kinyílásakor még kompakt pollinium hamar fellazul, megduzzad és a bibefelületre ráülve megtermékenyíti azt. 


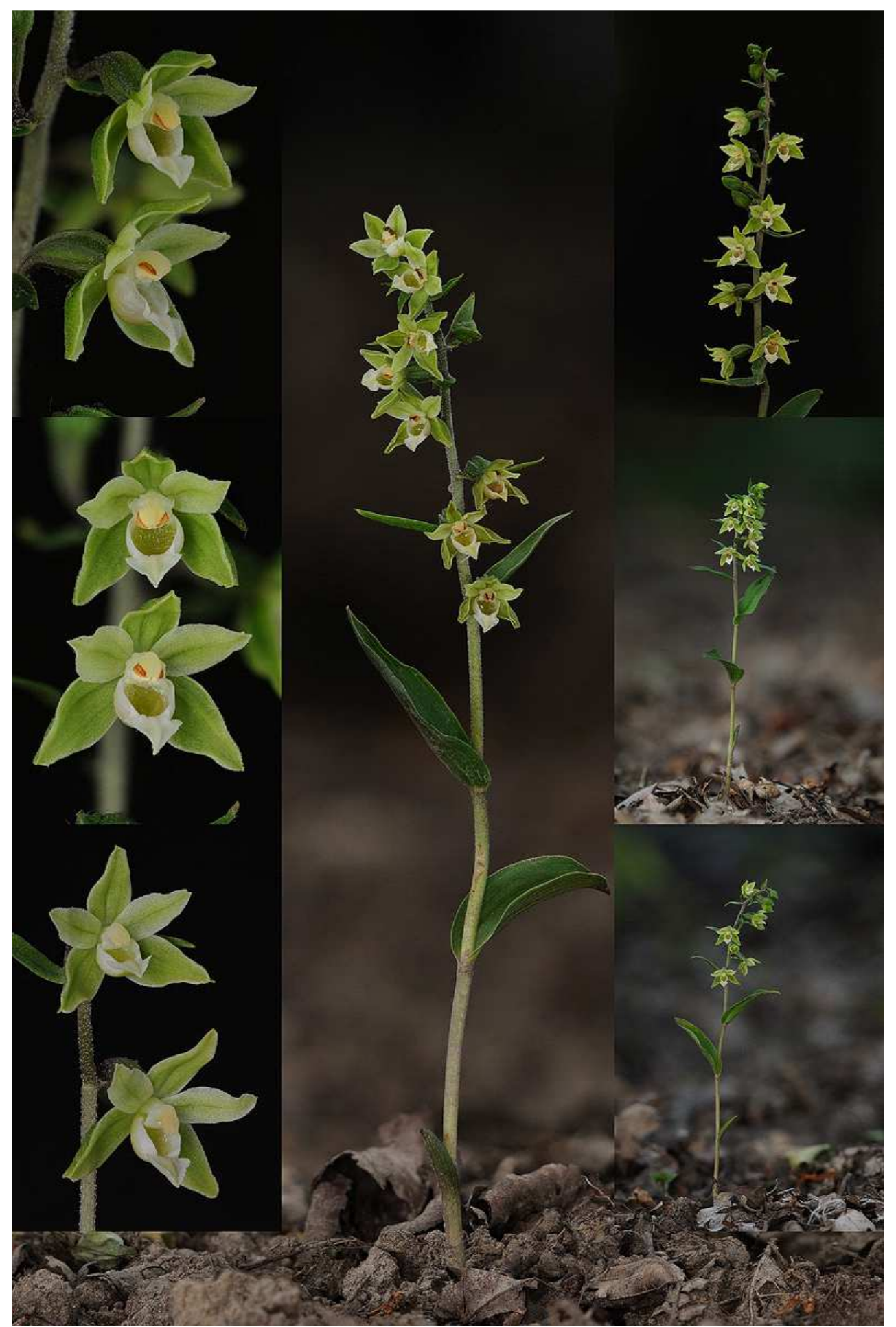

1. ábra. Az Epipactis pseudopurpurata a Vasvári-erdőben (Telki) (Csábi Miklós felvételei) Fig. 1. Epipactis pseudopurpurata from "Vasvári-erdő" (Telki, Hungary) (photos by M. Csábi) 


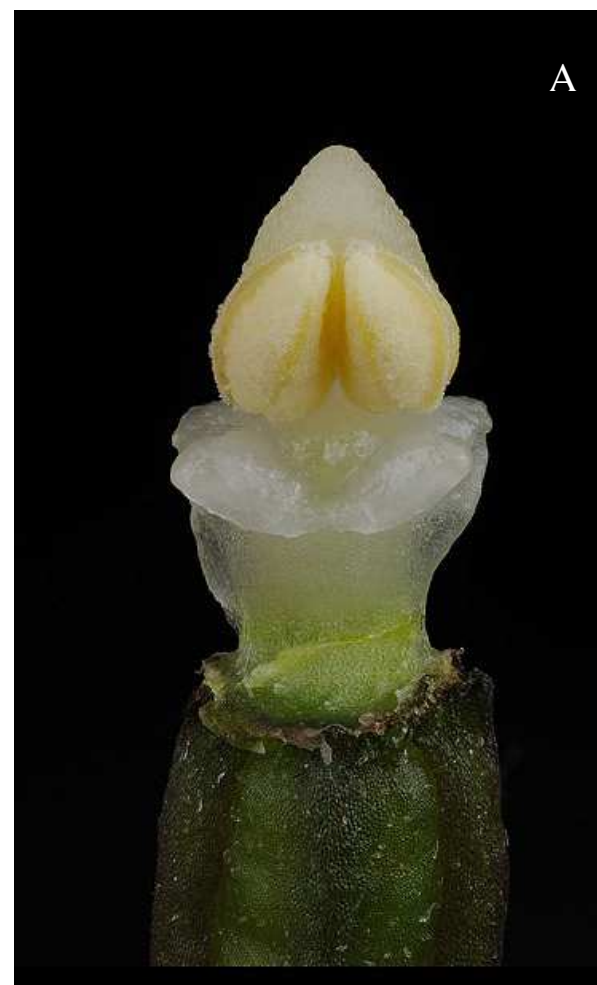

$\mathrm{C}$

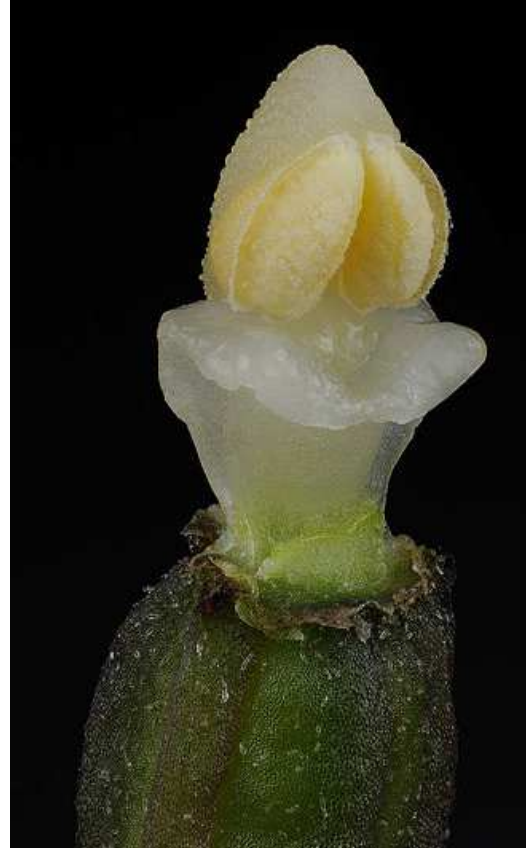

2. ábra. Az Epipactis pseudopurpurata (A, C) és E. purpurata (B, D) ivaroszlopa (Csábi Miklós felvételei) Fig. 2. The coloumn of Epipactis pseudopurpurata (A, C) and E. purpurata (B, D) (photos by M. Csábi)

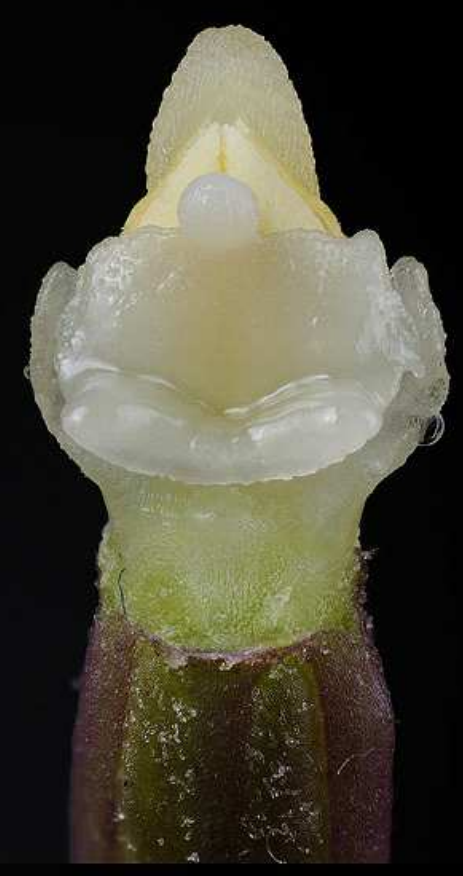

$\mathrm{D}$

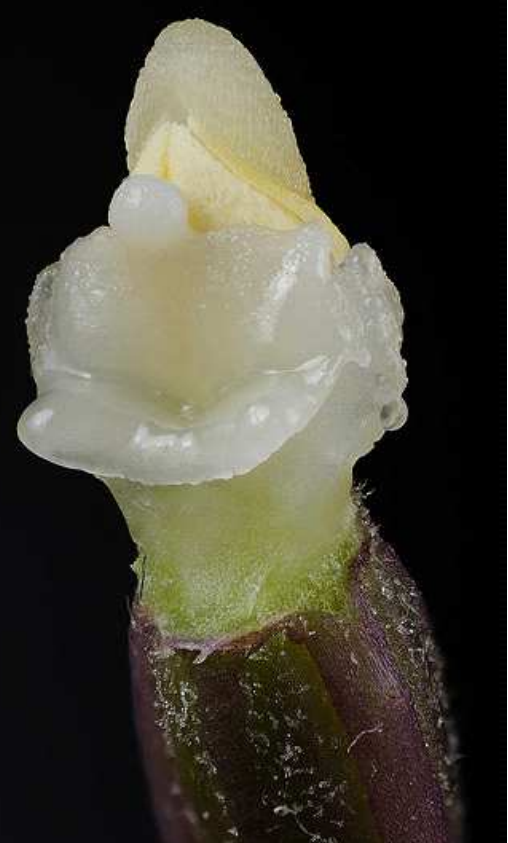




\section{Veszélyeztető tényezők}

Kis területre korlátozódó, kis egyedszámú, sérülékeny populációról van szó, élőhelyét elsősorban a vadállomány, a lovas és egyéb turizmus, valamint az erdészeti munkák veszélyeztetik. A területen élő, túltartott vadállomány kárt okoz, kitúrja az egyedeket. Az erdészeti munkák részlegesen korlátozva vannak - az erdő megnyitása nem kívánatos, különösen amiatt, hogy e nyári virágzású fajt jelentősen sújtják az aszályok. Szintén kockázatot jelentenek a környező, bolygatottabb területeken erősen terjedő özönnövények (például Impatiens parviflora DC.). Fokozottan védett fajjá nyilvánítását javasoljuk.

\section{Köszönetnyilvánítás}

Szeretnénk köszönetet mondani Molnár V. Attilának és Pavol Mered'anak a határozás megerősítéséért, Bíró Sándor természetvédelmi őrnek az élőhely megőrzéséért tett erőfeszítéseiért, továbbá Somlyay Lajosnak, aki a 2015-ös terepi állományfelmérésben segédkezett.

\section{Irodalom}

BAтоuŠEK P. (2009): Drei neue Bastarde der Gattung Epipactis Zinn (Orchidaceae). - Journal Europäischer Orchideen 41 (3-4): 507-518.

Delforge P. (2001): Guide des orchidées d'Europe, d'Afrique du Nord et du Proche-Orient. 2e édition. Delachaux et Niestlé, Lausanne \& Paris.

DelFoRgE P. (2006): Orchids of Europe, North Africa and the Middle East. - A\&C Black, London.

Devillers P. \& DeVILLERS-TERSChuREN J. (2000): Characters and ecology of Epipactis pollinensis on Mount Pollino, its place in the constellation of E. viridiflora and E. pseudopurpurata. - Natural. belges 81 (Orchid. 13): 353-361 + 8 figs.

MERED'A P. (1996): Epipactis pseudopurpurata Mered'a, spec. nova (Orchidaceae) - eine neue autogame Sitter-Art aus der Slowakei. - Preslia 68: 23-29.

Molnár V. A. (2003): Az Epipactis Zinn nemzetség fajai Magyarországon. - Flora Pannonica 1 (1): 44-57.

MoLnÁR V. A. (2009): Orchidaceae - Kosborfélék családja. - In: KiRÁLY G. (szerk.), Új magyar füvészkönyv. Magyarország hajtásos növényei. Határozókulcsok. Aggteleki Nemzeti Park Igazgatóság, Jósvafő, pp. 571-583.

MolnáR V. A. (szerk.) (2011): Magyarország orchideáinak atlasza. - Kossuth Kiadó, Budapest.

Molnár A. \& RoBAtsch K. (1997a): Epipactis mecsekensis A. Molnar et K. Robatsch spec. nova, eine neue Epipactis-Art aus Ungarn. - Journal Europäischer Orchideen 28 (4): 781-786.

Molnár A. \& RoвATsch K. (1997b): Epipactis tallosii A. Molnar et K. Robatsch spec. nova, eine neue Epipactis-Art aus Ungarn. - Journal Europäischer Orchideen 28 (4): 787-794.

Molnár V. A., VIDÉKI R., SUlYoK J. \& MÉSZÁRos A. (2004): Epipactis voethii Robatsch in Ungarn. - Journal Europäischer Orchideen 36 (3): 661-672.

Rоватsсн K. (1990): Epipactis bugacensis K. Robatsch, spec. nova: eine neue Epipactis-Art aus Ungarn. Berichte aus den Arbeitskreisen Heimische Orchideen 7 (1): 12-15.

Somlyay L. (2010): Epipactis futakii (Orchidaceae), a new species for the Hungarian flora. - Annales Historico-naturales Musei Nationalis Hungarici 102: 21-24.

SomLYAY L., MAKÁDI S. \& CSÁBI M. (2016): Adatok Budapest környéke flórájának ismeretéhez II. Kitaibelia 21 (1): 33-50.

SulYoK J. (2011): Nőszőfü-fajok térképezése a Bükki Nemzeti Park Igazgatóság működési területén. Zöld Horizont 6 (2): 6.

SulYoK J. \& MolnáR A. (1996): Az Epipactis pontica Taubenheim Magyarországon. - Kitaibelia 1: 66-70.

Beérkezett / received: 2015. 11. 22. • Elfogadva / accepted: 2016. 07. 04. 